\title{
33. INTERSTITIAL-WATER STUDIES, DEEP SEA DRILLING PROJECT SITES 415 AND 416
}

\author{
Joris M. Gieskes, Dennis Graham, and Rick Ellis, Scripps Institution of Oceanography, La Jolla, California
}

\begin{abstract}
Interstitial-water studies on samples collected during DSDP Leg 50 indicate that saline brines were advected through aquifers into the deeper sedimentary strata. Maxima in the magnesium concentration at about 500 meters at Site 415 and 600 meters at Site 416 support the hypothesis that high-magnesium silicates (palygorskite and sepiolite) are formed in situ in an environment conducive to silicate formation, i.e., in strata where silica recrystallization occurs.
\end{abstract}

\section{INTRODUCTION}

Sites 415 and 416 drilled during Leg 50 complete a large series of sites drilled off the northwest African continental margin. These sites are particularly interesting for interstitial-water studies, as the interstitial waters from previously drilled sites (Leg 14, Sites 139, 140; Leg 41, Sites 369, 370; Leg 47A, Site 397) all showed evidence of high salinities relative to normal sea water. In an earlier report (Couture et al., 1978), we speculated on the possibility that a brine flowed laterally through sandstone layers of Site 370. Manheim (1967), Presley et al. (1973), Manheim and Sayles (1974), Gieskes (1974), and Gieskes et al. (1978) have demonstrated that sandstones can serve as aquifers at great distances from land. Evidence from all these studies showed that the aquifers served as conduits for less-saline waters from a continental origin. For these reasons the data on Site 415 are of special interest because here a clear maximum in salinity demonstrates the flow of a saline brine through an aquifer. In this report we present the Leg 50 shipboard data as well as those obtained by further analyses in our home laboratory.

\section{RESULTS}

Our methods were essentially the same as those described by Gieskes (1974). Salinities were measured with a Goldberg refractometer (Manheim and Sayles, 1974). The data are presented in Table 1 and in Figures 1 and 2.

\section{DISCUSSION}

\section{Site 415}

The major feature at this site is the occurrence of a maximum in chlorinity and salinity at about 500 meters sub-bottom. This phenomenon can be explained best as a result of a brine inflow through sedimentary strata at these depths. Core recovery between 300 and 600 meters was rather sparse, but we submit that mudstones act as conduits for these brines.

As at Sites 369 and 370 (Couture et al., 1978) sulfate reduction is an active process and sulfate is essentially depleted in the upper 200 meters of sediments. Sedimen-
TABLE 1

Interstitial Water Data, Leg 50

\begin{tabular}{lrrrrrrrrrr}
\hline $\begin{array}{c}\text { Sample } \\
\text { (Interval in cm) }\end{array}$ & $\begin{array}{c}\text { Depth } \\
(\mathrm{m})\end{array}$ & $\mathrm{Na}^{\mathrm{a}} \mathrm{b}$ & $\mathrm{K}^{\mathrm{a}}$ & $\mathrm{Mg}^{\mathrm{a}}$ & $\mathrm{Ca}^{\mathrm{a}}$ & $\mathrm{Sr}^{\mathrm{a}}$ & $\mathrm{Cl}^{\mathrm{a}}$ & $\mathrm{SO}_{4}{ }^{\mathrm{a}}$ & $\mathrm{Alk}^{\mathrm{c}}$ & $\mathrm{s}^{\mathrm{d}}$ \\
\hline Hole 415 & & & & & & & & & & \\
$1-4,142-150$ & 6 & 456 & 12.7 & 61.8 & 10.2 & 0.15 & 570 & 21.5 & 3.41 & 35.2 \\
$2-1,140-150$ & 76 & 495 & 12.2 & 52.3 & 14.7 & 0.65 & 617 & 12.5 & 2.66 & 36.4 \\
$3-2,140-150$ & 141 & 506 & 11.5 & 50.1 & 16.7 & 0.96 & 636 & 8.4 & 2.84 & 37.7 \\
$4-4,140-150$ & 213 & 551 & 10.2 & 46.6 & 17.5 & 1.50 & 690 & 1.4 & 2.21 & 38.8 \\
$5-2,140-150$ & 277 & 586 & 9.5 & 48.1 & 18.9 & 1.43 & 731 & 0 & 2.31 & 40.7 \\
& & & & & & & & & & \\
Hole 415A & & & & & & & & & & \\
$8-1,140-150$ & 578 & - & - & 61.6 & 55.2 & - & 964 & - & 1.64 & 54.7 \\
$9-4,140-150$ & 649 & - & - & 58.9 & 57.4 & - & 941 & - & .96 & 52.8 \\
$10-1,140-150$ & 711 & - & - & 56.3 & 58.9 & - & 916 & - & 1.22 & 52.3 \\
$11-1,140-150$ & 796 & - & - & 52.2 & 59.3 & - & 831 & - & 1.36 & 47.9 \\
$12-1,140-150$ & 882 & - & - & 47.2 & 57.3 & - & 761 & - & 1.52 & 44.6 \\
$14-1,140-150$ & 1034 & - & - & 25.1 & 60.7 & - & 708 & - & .96 & 40.7 \\
& & & & & & & & & & \\
Hole 416A & & & & & & & & & & \\
$1-1,140-150$ & 148 & 514 & 10.2 & 46.4 & 16.0 & 0.71 & 637 & 6.7 & 2.1 & 37.7 \\
$2-2,140-150$ & 301 & 528 & 9.6 & 43.8 & 18.4 & 0.83 & 660 & 2.0 & 3.12 & 38.5 \\
$3-2,140-150$ & 453 & 577 & 8.4 & 39.0 & 25.9 & 1.18 & 717 & 0 & 2.52 & 41.0 \\
$6-2,140-150$ & 890 & - & - & 58.5 & 48.3 & - & 948 & - & 1.32 & 55.0 \\
$7-2,140-150$ & 995 & - & - & 45.3 & 37.9 & - & 797 & - & .56 & 46.2 \\
\hline
\end{tabular}

Note: Only sample 6 had a manganese concentration of $19 \mu$ moles/1; the remainder had concentrations well below our detection limit, i.e., $<5 \mu$ moles $/ 1$.

$a_{\mu \text { moles/liter. }}$

${ }^{\mathrm{Na}} \mathrm{by}$ difference.

'milliequivalents/liter.

dSalinity in parts per thousand.

tation rates during the last 10 m.y. have generally been less than $2 \mathrm{~cm} / 1000 \mathrm{yr}$, but organic-carbon contents (Kvenvolden, this volume) are between 0.2 and 1.0 per cent in the upper 300 meters of the sediment column. The alkalinity values do not show a pronounced maximum, as is often the case in sediments from sites with significant sulfate reduction (Gieskes, 1974, 1975). Thus bicarbonate produced during sulfate reduction is effectively removed, perhaps in part in the form of calcite. Galimov et al. (this volume) report $\delta^{13} \mathrm{C}$ values of less than zero for calcites in this interval, which could be caused by incorporation of biogenically derived carbonate in the carbonate matrix (Anderson and Lawrence, 1976).

Magnesium shows a minimum at 200 meters, implying its chemical removal in the upper 200 meters. Presumably the $\mathrm{Mg}^{++}$is taken up in silicates, either for upgrading detrital silicates or for the formation of new 

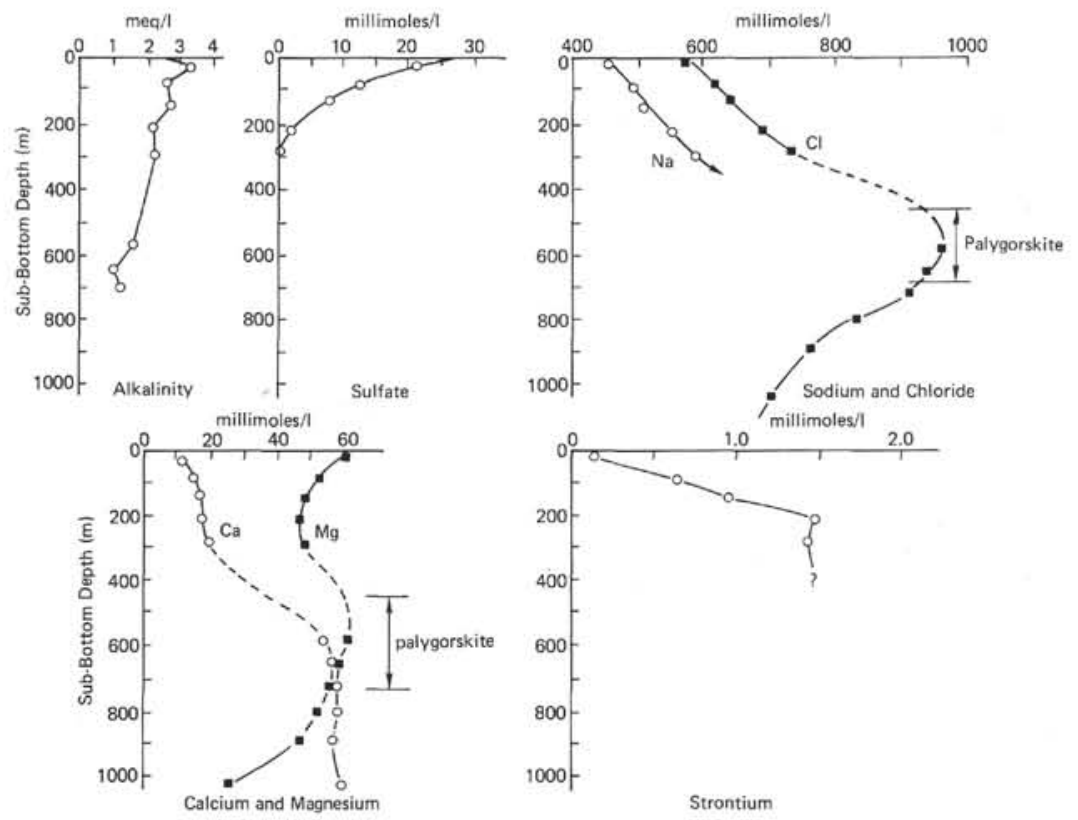

Figure 1. Interstitial-water data, Site 415.
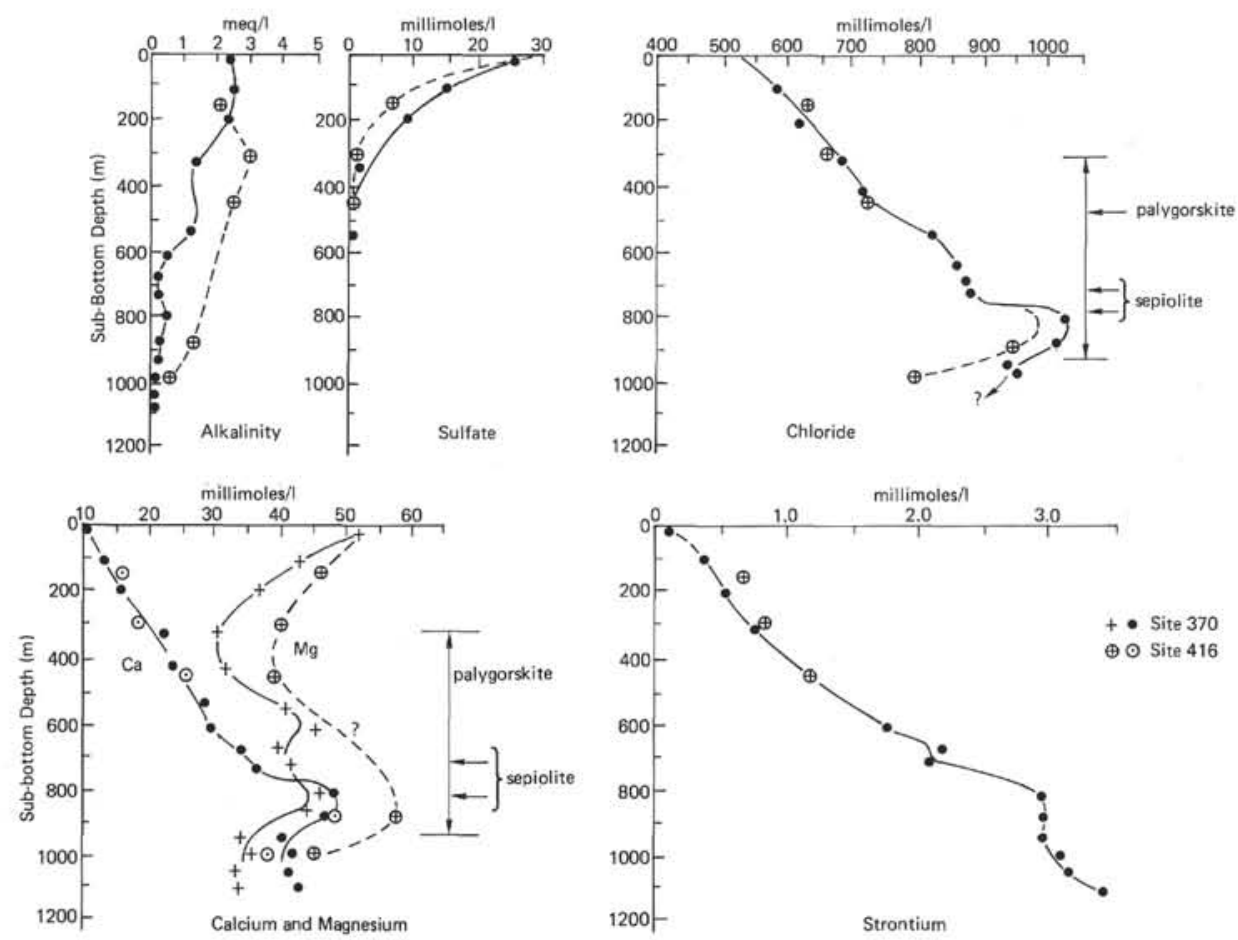

Figure 2. Interstitial-water data, Sites 370 and 416.

silicates as a result of alteration of igneous material, or precipitation with dissolved silica. Such processes, of course, would also require a decrease in alkalinity. Sediments in this area are characterized by the magnesium being contained in palygorskite and sepiolite (Rex, 1970; Fan and Rex, 1972; von Rad and Roesch, 1972; Couture, 1977; Couture et al., 1978; Mélières, 1978; von Rad et al., 1978; Riech, this volume; Chamley et al., this volume). These minerals occur in particular in the Eocene and upper Paleocene sections. Couture (1977) and also von Rad et al. (1978) suggest that palygorskite and sepiolite, particularly when associated with recrystallized biogenic silica, is formed in situ. These authors cite in particular the textural evidence that indicates authigenic growth intimately related to opal recrystallization. On the other hand, Mélières (1978) suggests that the palygorskite and sepiolite were redeposited at Site 415 , inasmuch as these minerals occur in thick sections of similar age in the basins of the West African coast, e.g., the Senegal Basin (Millot, 
1970). The interstitial-water data support the hypothesis of the formation of these minerals in an environment of brine-enhanced magnesium combined with dissolved silica supplied during diagenesis. Dissolution of detrital clay could have served as a source of aluminum. Such a mechanism, of course, has previously been proposed by Peterson et al. (1970).

Concentrations of dissolved magnesium decrease below 600 meters, presumably as a result of diagenetic reactions occurring deeper in the hole.

Amounts of dissolved strontium increase very rapidly downhole and are probably related both to carbonaterecrystallization processes and to the influx of brines in the deeper strata (Couture et al., 1978).

\section{Site 416}

The interstitial-water data from Site 416 are essentially identical to those of Site 370 (Leg 41). In Figure 2 we present the data for both Sites 370 and 416. Though slight differences are apparent in some of the profiles, particularly for magnesium, the agreement is generally good; the quality of the data from Site 370 is probably superior. Although the main objective of drilling Site 416 was to penetrate deeper than at Site 370 , interstitial waters were not obtained below 1000 meters. In the future we hope to establish whether a reversal occurs in the salinity below 1100 meters by squeezing some stored sediments from the deeper strata.

The magnesium-concentration minimum around 400 meters is confirmed by our data. The maximum at about 650 meters may, again, be related to an influx by lateral brine advection. The other alternative is that processes involving the uptake of magnesium have become active in the strata around 400 meters only in more recent times, as appears to be the case at Site 368 (Couture et al., 1978). However, the data for Site 415 strongly support the "brine hypothesis."

\section{CONCLUSIONS}

The evidence presented in this report indicates that brines with high magnesium concentrations are advected through aquifers, leading to maxima in the magnesium concentrations at depths of 500 meters at Site 415 and 600 meters at Site 416. At these depths highmagnesium silicates, often associated with recrystallized biogenic silica, are characteristically present in the sediments. Our data support the contention that a significant portion of these magnesium minerals was formed in situ and that such formation processes are probably still occurring in association with continued recrystallization of silica.

\section{ACKNOWLEDGMENTS}

This work was generously supported by NSF Grant OCE 76-201518 (J.M.G.).

\section{REFERENCES}

Anderson, T.F. and Lawrence, J.R., 1976. Stable isotope investigations of sediments, basalts, and authigenic phases from Leg 35 cores. In Hollister, C.D., Craddock, C., et al., Initial Reports of the Deep Sea Drilling Project, v. 35: Washington (U.S. Government Printing Office), p. 497-505.

Couture, R.A., 1977. Synthesis of some clay minerals at $25^{\circ} \mathrm{C}$; Palygorskite and Sepiolite in the Oceans, Ph.D. thesis, University of California, San Diego.

Couture, R.A., Miller, R.S., and Gieskes, J.M., 1978. Interstitial water and mineralogical studies, Leg 41 . In Lancelot, Y., Seibold, E., et al., Initial Reports of the Deep Sea Drilling Project, v. 41: Washington (U.S. Government Printing Office), p. 907-914.

Fan, P.F. and Rex, R.W., 1972. X-ray mineralogical studies, Leg 14. In Hayes, D.E., Pimm, A.C., et al., Initial Reports of the Deep Sea Drilling Project, v. 14: Washington (U.S. Government Printing Office), p. 677-726.

Gieskes, J.M., 1974. Interstitial water studies, Leg 25. In Simpson, E.S.W., Schlich, R., et al., Initial Reports of the Deep Sea Drilling Project, v. 25: Washington (U.S. Government Printing Office), p. 361-394.

1975. Chemistry of interstitial waters of marine sediments, Ann. Rev. Earth Planet Sci., v. 3, p. 433-453.

Gieskes, J.M., Lawrence, J.R., and Galleisky, G., 1978. Interstitial water studies, Leg 38. In Talwani, M., Udintsev, G., et al., Initial Reports of the Deep Sea Drilling Project, v. 38 Supplement: Washington (U.S. Government Printing Office), p. 121-135.

Manheim, F.T., 1967. Evidence for submarine discharge on the Atlantic continental slope of the United States and suggestions for further research. New York Acad. Sci., Trans. v. 29 , p. $839-853$.

Manheim, F.T. and Sayles, F.L., 1974. Composition and origin of interstitial waters of marine sediments, based on deep sea drill cores. In Goldberg, E. (Ed.), The Sea, v. 5, New York, (John Wiley and Sons), p. 527-568.

Mélières, F., 1978. X-ray mineralogy studies, Leg 41, Deep Sea Drilling Project, Eastern North Atlantic Ocean. In Lancelot, Y., Seibold, E., et al., Initial Reports of the Deep Sea Drilling Project, v. 41: Washington (U. S. Government Printing Office), p. 1065-1086.

Millot, G., 1970. Geology of clays: New York (Springer).

Peterson, M.N.A., Edgar, N.T., von der Borch, C.C., and Rex, R.W., 1970. Cruise leg summary and discussion. In Peterson, M.N.A., Edgar, N.T., et al., Initial Reports of the Deep Sea Drilling Project, v. 2: Washington (U.S. Government Printing Office), p. 413-430.

Presley, B.J., Culp, J., Petrowski, C., and Kaplan, I.R., 1973. In Heezen, B.C., MacGregor, I.D., et al., Initial Reports of the Deep Sea Drilling Project, v. 20: Washington (U.S. Government Printing Office), p. 805-809.

Rex, R.W., 1970. X-ray mineralogical studies, Leg 2. In Peterson, M.N.A., von der Borch, C.C., et al., Initial Reports of the Deep Sea Driling Project, v.2: Washington (U.S. Government Printing Office), p. 329-346.

von Rad, U. and Rösch, H., 1972. Mineralogy and origin of. clay minerals, silica and authigenic silicates in Leg 14 sediments. In Hayes, D.E., Pimm, A.C., et al., Initial Reports of the Deep Sea Drilling Project, v. 14: Washington (U.S. Government Printing Office), p. 727-751.

von Rad, U. and Rösch, H., 1972. Mineralogy and origin of in continental margin sediments off Northwest Africa. In Lancelot, Y., Seibold, E., et al., Initial Reports of the Deep Sea Drilling Project, v. 41: Washington (U.S. Government Printing Office), p. 879-906. 